\title{
FINANCIAL INSTRUMENTS AND THEIR IMPACT ON THE GROWTH OF INVESTMENT - A STUDY ON THE LIBYAN MARKET
}

\author{
Abdulbaset Ali Alhaj ${ }^{1 i}$, \\ Abdullah Mohammed Awn', \\ Al Taher Khalifa Abdusalam Alaswed ${ }^{3}$ \\ 1University of Business Administration Jinan, \\ Lebanon \\ ${ }^{2}$ Management \& Science University, \\ Malaysia \\ ${ }^{3}$ University of Zawia, \\ Libya
}

\section{Abstract:}

Purpose: The aim of this study was to explore the relationship between Financial instruments and growth of investment. Design/Methodology/Approach: The distributed questionnaires include 300 clients from banks and companies represented in Tripoli. The data collected was analyzed using SPSS- SEM. Results: The obtained results showed that indicated that, despite the modest progress made in a very short time regarding all indicators which the paper calculated, however, it can be said that Libyan stock market remain largely underdeveloped, small and relatively inefficient. Its market capitalization to GDP is very low and investors have no access to long-term capital. In addition, the market still has very low liquidity and investors still have a limited choice of financial instruments and face liquidity problems. Originality/Value: This study contributes significantly to the importance of diversity in the use of financial instruments that help in the growth of investment. The study added a new discussion, which is the disclosure that financial instruments affect the growth of domestic investment, especially by easing financing restrictions, which allows companies to increase investment in response to increased demand for production. The main finding is that the structure of the financial system does not have an independent effect on investment growth, in the sense that it does not enhance the response of investment to changes in production, whereas financial development makes investment more responsive to output growth. Thus, instead of promoting a specific type of financial instrument, countries should implement policies that reduce transaction costs in financial intermediation and enforce the rights of creditors and investors. This will facilitate the development of banks and stock markets, which will stimulate the growth of domestic investment.

i Correspondence: email basset.nmc@gmail.com 
JEL: D53; G14; O16

Keywords: investment, financial instruments, Gross Domestic Product (GDP), Libyan stock market

\section{Introduction}

Market or stock market-based financial systems are better at encouraging and growing domestic investment. The different financial instruments affect the growth of investment, especially by easing the constraints of investment financing, and that the financial systems that work better allow companies to invest more in response to the increasing demand for production. It follows that at the aggregate level, developed financial systems are associated with a stronger response to domestic investment to increase per capita GDP. This analysis is derived from the accelerator theory, which predicts a positive relationship between investment and changes in output (Ndikumana, L. 2005).

Financial instruments have a number of advantages, namely - a transparent procedure for pricing the exchange market and a variety of trading tools that allow the potential investor to invest capital in order to make a steady profit that fully meets the requirements of physical security, or to achieve financial independence (Abuselidze, G. \& Slobodianyk, A. 2019). Over the past decade, in many countries of the world, behind the entrepreneurial system, new capital markets are emerging and investment alternatives are expanding. Despite all the changes, investors want to get a big profit, but they do not want to expose themselves to the associated risks, and this in turn creates the need to implement new investment strategies that are more sophisticated or raise the search for new investment alternatives to the usual options in order to invest their capital. Investors are often concerned about the risk of losing their entire investment (Madhavan, 2016).

An investor can refuse without thinking important classes of investment assets, bonds, or stocks, even if this asset class plays an important role in developing the best strategy for achieving goals. Return on assets and risk assessment, which is used in both the normal and the policy of alternative investment tools must be prospective and effective and reflect the correlation of basic economic risks with respect to different assets, so the portfolio structure for many investors accurately reflects the level of comfort and investment advantages that they enjoy, but it is far On achieving the stated financial goals. The financial instruments market requires investors or investment advisors something more than a current assessment of the client's condition, that is, the development of the corresponding strategies, because in most cases, the client does not have the conceptual knowledge or competence sufficient to understand the necessity to follow the recommendations contained in his own interest that encourage the growth of investment (Abuselidze, et al., 2018).

At present, the largest institutional investors and ETFs invest a large portion of their portfolio in economic activities-related assets. Financial instruments can pool 
resources for adaptation, create a new factor in investment attractiveness and make the investment process more aware and less speculative. Governments are also interested in developing various financial instruments as they can play an important role in the movement of capital flows from the financial sector to industrial and investment projects (Shaydurova, et al., 2018).

\subsection{Objectives of the Study}

The fundamental aim of this paper is to examine the Financial instruments and their impact on the growth of investment - A study on the Libyan market. The specific objectives are as follows:

1) An attempt to define the role of the Libyan financial market through the concept of the global financial market and the roles it is supposed to play to support the wheel of growth and investment.

2) Compare the role that the Libyan financial market plays, through its institutions and tools, and clarify the location and size of the investment structure for the Libyan market.

\section{The Rationale for The Study}

Financial investment in the stock market is important in Libya. This can be attributed to the increase and growth of real investment in the country and the need to adhere to services and economic growth (Al-Garhi, 2007; Dosky, 2008; Allam and Rizvi, 2017; Rashid et al., 2018). To our knowledge, no study has been published using a theoretical model regarding financial instruments and their impact on investment growth, either in Libya or in any part of the Arab world. Therefore, this study addresses this knowledge gap through real investment. This goal can be achieved, especially with regard to investment and economic growth. Moreover, diversity in different financial instruments will reduce the burden between the parties and prevent potential abuse of the weaker party by the stronger party (Abdel Rahman et al., 2014). This type of investment achieves economic growth aspirations that support social and economic development in various fields.

\section{Literature Review and Development of Conceptual Framework}

Several empirical studies have provided evidence that strongly supports the view that financial development has a positive effect on various aspects of real economic activity, including investment growth (Ndikumana, 2000; Rajan \& Zingales, 1998; Demirgu \& Maksimovic, 1996), Employment, Productivity, and Long-Term Economic Growth (Levine et al., 2000; Beck et al., 2000b; Levine \& Zervos, 1998; Levine, 1997). Evidence indicates that expanding and deepening the financial system leads to faster economic growth. Without completely settling the issue of causality trend, this empirical literature has made significant progress in establishing that the external component of financial 
instruments has a positive effect on economic growth and investment (Ferracuti, E., \& Stubben, S. R. 2019). To identify investment opportunities for companies from market prices and thus reduce information uncertainty. For example, company public disclosures may increase or decrease the imparting of information on stock prices by affecting investors' incentives to produce private information (Gao and Liang, 2013; Banerjee et al., 2018; Chen et al., 2014; Chen et al., 2018; Goldstein and Yang, 2019) or by attracting stock trading. Moreover, the share price not only serves as an indicator of growth potential but also as a tool for managers to disclose the proposed course of action to investors (Han et al., 2016). Financial investment in the agri-food sector has grown significantly since the 2007-08 food crisis, which saw food prices soaring and concerns about potential future food shortages in a resource-constrained world. Much of this economic investment has been associated with large-scale institutional investors - such as pension funds, hedge funds, asset management companies, and university and founding endowment funds - who typically invest large amounts of money with longterm passive investment strategies. A large proportion of these investments have been channeled through new financial investment vehicles linked to the sector, such as commodity index funds (CIFs; for example, Ghosh, 2010) and real estate investment funds (REITs) that include agricultural land located around the world (for example, Fairbairn, 2014). The side effects of these new types of investment in the agri-food sector and the economy, ranging from increased volatility in food prices to fragile land rights for farmers, have received attention from global bodies such as the Food and Agriculture Organization, the World Bank and the Group of Twenty, to identify appropriate international governance responses (Clapp \& Isakson, 2018). While financial and economic investment has attracted a great deal of attention, recent years have also seen financial investors pour money into equity-linked funds and bonds linked to the investment sector. Equity-related mutual funds include both mutual funds and exchange-traded funds that invest in a company's shares or track the performance of a group of companies that are publicly traded on the stock exchange, according to at least one estimate. Equity-related mutual funds were their peak in the period 2010-2014, With about a third of global financial investment in the economic investment sector (Valoral Advisors, 2010, 2015). Although private equity investor investments in recent years have grown substantially (i.e., investing in private companies that are not publicly traded; Burch \& Lawrence, 2013; Valoral Advisors, 2018a), equity-linked funds based on publicly traded companies remain an important investment vehicle for investors. Interested in the growth of their investment. Despite its importance over the past decade or more, the scientific community and political communities have paid far less attention to investing in equity-related financial investment than in speculating on commodities and land. However, it is not at all clear that the effects of equity-related investments are completely neutral (Clapp, J., 2019).

Stock markets provide a better platform for people compared to traditional banking investments. People can invest their money and get huge profit if they invest reasonably. According to Khan et al. (2018), equity investments are more profitable than 
bank deposits and bonds. Bonds occupy a position no less important in the stock market. Using bonds is associated with less risk than using bank lending. The company undertakes to pay the interest and the loan body until the moment of bankruptcy. If the financial condition of the company worsens, the investor will be affected by the decline in the value of the shares and the termination of the dividend payments. The bonds are repaid until the company declares bankruptcy, since high interest is guaranteed, its returns are lower in inventory. The investor, who wants to make more profit from bank deposit or purchase of bonds, boldly declares that stocks are a suitable tool for making profits, each, and growing investment as the risk-return ratio allows him to make a longterm profit and a guaranteed investment (Zakharkin et al., 2018). that with an increase of the investment horizon, the volatility of stocks significantly decreases, making them more attractive for investors as compared with bonds, the volatility of European stock markets was researched by B. Harrison, W. Moore (2012), D. Gjika, R. Horvath (2013), J. Okicic (2014), A. Hepsag (2016), B. Yavas and L. Dedi (2016).

According to Isola and Mesagan (2016), developing the money and capital markets is crucial for advancing economic progress. The money market is where short-term debts such as treasury bills, commercial bills and others are traded to meet the short-term obligations of the fund users. On the other hand, the capital market is where long-term equity and debt capital are raised for long-term investment (Jalloh, 2009; Mesagan and Amadi, 2017). Thus, developed financial institutions help improve savings and investments, as well as generate financial resources to stimulate them to grow output (Gibson and Tsakalotos, 1994; Mesagan and Nwachukwu, 2018).

Other studies have found evidence in favor of a market-based financial system with more technical econometric approaches. Yeh, Huang, and Lin (2013) show that the structure of financial instruments is related to both economic growth and investment and its volatility. Using a panel dataset of 40 countries from 1960 to 2009, they found that a market-based financial system supports the country to develop faster although it also leads to higher volatility in the long run. Another study that does not support the financial instruments view but rather reinforces the market-based view is Lewintel, Khan, Leon Gonzalez, and Lee (2016). They analyze a sample of 33 high-income and 36 middle-income and low-income countries during the period 1989-2011 using the Bayesian framework. A financial system that is more market dependent as compared to the banking system is one of them that contributes to economic growth and investment in high-income countries. Moreover, neither the structure of financial instruments nor financial development affects growth and investment in middle and low income countries. Castro et al. (2015) investigated the impact of financial instruments on investment decisions of Brazilian companies from 1998 to 2006. After controlling for the level of financial development, the generalized method of moment estimation results shows that the investment behavior of financially restricted companies is strongly influenced by the structure of financial instruments. The result supports the marketbased view to alleviate the company's dependence on internal resources. 
Liu and Zhang (2018) use the least square and generalized two-stage method of moments to explore the internal mechanism between financial instrument structure and economic growth and investment in China's provinces during the period 1996 to 2013. Their findings support the market-based view as the structure of financial instruments has a significant impact on Economic growth. However, its impact on economic and investment growth. Another literary field indicates that both banks and markets are important to growth and investment but their relative role changes with economic development (Boyd and Smith, 1998; Rajian and Zingales, 1998; Lin, Sun, and Jiang, 2009; Thumrongvit, Kim, and Pyun, 2013; Demirgüç-Kunt et al., 2013). Demirgüç-Kunt et al. (2013) use quantitative recording to find out how different the effects of banks and the stock market on investment and economic growth with economic development. They find it similar to economies as the role of stock markets and financial instruments in promoting economic growth increases while the role of banks diminishes. In other words, the banking system plays an influential role in promoting growth and investment early in the stages of economic development. However, as the investment grows, the leading role is transferred to the stock and bond market. However, not only is there a lack of consensus in the literature about the structure of financial instruments and the relationship of growth and investment, but the literature often ignores the fact that the unbalanced structure of financial instruments or other distortions of the macro economy may affect the way the financial structure affects economic activities. In this paper, we bridge the gap by examining how the impact of financial instruments on financial development and investment growth evolves, the "imbalance" of the financial instruments structure, macroeconomic instability and investment growth $(\mathrm{Chu}, \mathrm{L}$. K. 2020).

\subsection{Theory of Internal Economic Growth}

According to modern economic growth theory, factors contributing to economic growth include capital, human capital, and technology. While quite often overlooked, institutions, which define and enforce property rights, can also affect economic performance because they reduce transaction costs and uncertainty throughout exchange activities. As such, a theory of growth is incomplete without a theory of institutions. Institution as a rule of resource allocation, on the one hand, encourages people to increase capital investment, accelerating the process of technological progress; and on the other hand, optimizes resources allocation to boost efficiency (Li, Z., Chu, Y., \& Gao, T., 2020). The theoretical basis for this study is mainly based on the theory of internal growth and investment, which calls for estimating the rate of growth of individual output using fiscal policy. The theory of internal growth says that economic growth is primarily a result of influencing internal factors rather than external forces. Before the development of the new trade theory, traditional international trade theory was largely incapable of explaining intra-industry trade or intra-country or intra-regional trade. Gravity models suggested that most trade tended to be local. The development of a new trade theory on the basis of the Dixit-Stiglitz modeling framework (Dixit \& Stiglitz 1977), subsequently 
led to a renewed interest in domestic and intra-industry trade with the aim of local economic growth (McCann, P., \& Van Oort, F., 2019).

The theory of internal growth says that investing in human capital, innovation and knowledge contributes significantly to economic growth. The theory also focuses on positive external factors and indirect effects on investment growth that will lead to economic development. The theory of internal growth primarily states that the rate of long-term economic growth depends on policy measures from laws and regulations. The more we understand these issues, the more we appreciate their complexity, and simple parsimonious model frameworks are rarely sufficient for explaining them. Moreover, after almost three decades of analytical and empirical debates, it is still not clear whether or when regional diversity or specialization are growth-enhancing phenomena (Beaudry \& Schiffauerova, 2009; Melo et al., 2009; De Groot et al., 2015), thereby questioning some of the claims of urban economics to have made significant strides forward (Ellison et al. 2010; Kerr \& Kominers, 2015; Faggio et al., 2017). One of the implications of the theory of internal growth is that policies that embrace openness, competition, change and innovation will foster investment growth (Fadare, 2010). The internal growth model is an economic theory that claims that economic growth is created from within the system as a direct result of internal processes. Specifically, the theory suggests that strengthening the nation's human capital will lead to economic growth by developing new forms of technology, organized labor market laws, and effective and effective means of production (Uremadu, S. O., \& Onyele, K. O., 2019).

\subsection{Investment Growth}

Several empirical studies have provided evidence that strongly supports the view that financial development has a positive effect on various aspects of real economic activity, including investment growth (Ndikumana, 2000; Rajan and Zingales, 1998; DemirguKunt and Maksimovic, 1996), Employment, productivity and long-term economic growth (Levine et al., 2000; Beck et al., 2000b; Levine and Zervos, 1998; Levine, 1997). Evidence indicates that expanding and deepening the financial system and its instruments leads to faster economic growth. Without fully settling the issue of causality trend, this empirical literature has made great progress in proving that the external component of financial development has a positive effect on economic growth and investment Investors can take advantage of new investment strategies for growth in order to focus more precisely on stocks or other investments that offer above-average profit potential. When it comes to investing in the stock market, there are always a variety of approaches that can be taken. They argued that geography, culture, and other factors were not the fundamental factors of economic growth. Furthermore, the impact of institution on economic growth is stable; in contrast, when limiting the impact of institutional variables, the impact of human capital on long-term economic growth is limited accordingly as well. This suggests that the institution is the root cause of longterm economic growth and played a role through material capital, human capital, and total factor productivity. Based on different indictors of economic institutions-for 
example, International Country Risk Guide, the openness index, Polity IV (investigated by Political Instability Task Force), the Worldwide Govern Index, and World Development Indicators (WDI) - a number of empirical studies also have proved that institution did have a positive effect on economic growth [Iqbal and Daly (2014), Nawaz (2015), Wietzke (2015), Fernandez \& Tamayo (2017), Langlois (2017), and Nikolaev \& Salahodjaev (2017).

However, the goal is always the same always, and growth investors constantly seek out individual stocks or equity-related investments - such as mutual funds or exchange-traded funds (ETFs) - that brace for growth and offer the potential for a greater profit. Investments must be aligned with short and long-term financial goals, risk tolerance, and a number of other factors. However, there are basic techniques, principles, and strategies that investors can follow that will suit any investment plan, therefore, highquality integrative institutions and (adopting) productive regulatory measures are required to stimulate and sustain competitive, growth-oriented and investment-oriented capitalism (Acemoglu \& Robinson, 2012; Baumol et al., 2007; Bloom et al., 2018). Trade and associated integration have a positive effect on institutional quality and organizational routine as well, confirming the empirical results that trade has an indirect effect on income through improving institutional quality, albeit not having much direct effect (Bloom et al., 2017; Rodrik et al., 2004; Roderick, 2017).

\subsection{Financial Instruments}

The birth of financial markets can be linked to the dawn of history with the first stable settlements. Farmers used crops to exchange their seeds for other products: this is how the first prototype of markets were born. Modern financial markets are of course more structured and complex. A financial market is the environment where financial assets are traded. It is the place where potential buyers and sellers participate in an exchange of assets such as stocks, bonds, currencies (Forex) and derivatives (financial instruments linked to an underlying asset), (Calesso, A., Conti, M., \& Grasselli, M., 2020). At the same time, the practical application of derivatives in modern conditions is most observed in the field of institutional financial investments and is used for hedging risks, as well as the basis for the construction of complex financial products that combine a whole set of investment opportunities. At the same time, the very nature of the derivative financial instrument, based on the risk and probabilistic indicators of the investment efficiency of the underlying financial asset. Thus a general definition of a derivative financial instrument, "On the securities market" includes a Treaty, which may in particular provide for the obligation of the parties periodically or in a lump sum to pay monetary amounts depending on changes in the price of goods, securities, currency exchange rates, interest rates, inflation, prices of other derivative financial instruments, as well as the values of the statistical indicators of the physical, biological, and chemical indicators of the state of the environment, or from changes in values, calculated on the basis of the above indicators (Chikulaev, R. V., 2020). 
Over the past decades, dynamic and economic changes across the financial markets have included the introduction of innovative financial instruments that contribute to global financial diversification and investment. The category of innovative financial instruments is highly heterogeneous, for example, in terms of its rate of expansion; Exchange Traded Funds (ETFs) are among the most popular financial instruments in the financial instruments market (Marszk, A., \& Lechman, E., 2020). ETFs are funds structured to mimic the performance of selected financial assets, usually stock indices. The difference between ETFs and traditional investment products (such as mutual funds) is that ETF units are similar to financial instruments such as stocks or listed bonds because they are bought and sold through exchanges. The increasing popularity of ETFs, the increase in the amounts involved and the turnover rate, is mostly boosted by lower trading costs, lower tracking errors, high liquidity (in some countries) and higher tax efficiency (Agapova, 2011; Madhavan, 2016; Ben-David et al., 2017; Lettau \& Madhavan, 2018).

\section{Discussion of the Result}

Various financial efforts, plans and tools, mobilizing the necessary financing and directing investment growth remains a major challenge for investment projects. Through a descriptive research analysis, the paper indicates that financial instruments lie in the heavy and time-consuming procedures, unqualified processes, minimum scale requirements and co-financing that encourage investment growth. A stable regulatory environment emerges in each as a crucial factor, as it can prevent many investors from accessing the financing and investment scheme. The paper proposes that in order to design effective investment plans targeting the financial market, among other things, policymakers should consider the element of affordability, nature of financing, project size, and technical support for specific schemes. In order to maximize the use of funds, a better understanding of the local needs in the market is required so that the relevant financial instruments are adjusted accordingly. Financial instruments are expected to make a significant contribution to the objectives of the investment promotion policy in the coming years, especially in the case of integrating social and environmental impact in the design of future gadgets. The findings presented in this paper are useful in relation to policies aimed at promoting and growing domestic investment. Evidence indicates that it may not be worthwhile to spend resources in an attempt to enhance a particular type of financial instrument. This is especially important for the least developed countries which suffer from scarcity of resources. Instead, countries will benefit from reducing policy uncertainty, strengthening the regulatory framework, and enforcing the rights of creditors and investors. This will create an environment that facilitates the development of banks as well as stock markets, which will stimulate investment growth.

The results also confirm that traditional investment goals are somewhat irrelevant to supportive financial instruments. This is an important result for Libyan banks and companies due to their limited financial resources, which are spent in the first place and 
which are needed due to the risks of falling prices. Therefore, banks can operate differently in comparison to other companies that issue financial instruments such as stocks and bonds. So, investors expect an emotional return that offsets their financial efforts. Since we are giving an overview of the investment behavior of actual and potential individual Libyan investors of backer-based financial instruments, further research should focus more on specific financial instruments. As mentioned above, there are differences between the individual machines. While classic investment objectives such as financial, yield or safety are likely to be more clear in the context of stocks and bonds, in addition, future research in financial markets and investment should consider the importance of Islamic bonds (Sukuk) as a suitable performance for investing in the stock market, which is characterized by little risk. On investing in stocks and conventional bonds, the focus of the research should be on the empirical evaluation of the most appropriate financial instrument. Given the high regulatory standards for issuing Islamic bonds, crowdfunding, which remains relatively unregulated, may be attractive and A cost-effective tool with fewer financial capabilities and resources, which mainly focuses on individual and group projects. Therefore, the basis for financing and investment projects in Islamic bonds is firm and available, which simplifies future campaigns in this financial instrument in which the supporter participates.

\section{Managerial Implication of the Study}

The results indicate the similarities but also the differences between actual and potential future individual investors and non-investors in financial instruments related to equities and conventional bonds. In addition, it underscores new insights into investment behavior and individual decisions. Therefore, the respondents who have knowledge of financial instruments have already invested in financial instruments. However, the results of this study have many administrative implications because the results show that the behavior of individuals in financial investment in financial instruments and the impact on investment growth are classified as the least specific investment in the Libyan market. Therefore, marketers in banks and the Libyan stock market should ensure that they deal with customer services or investors to educate the public about the importance of investment and financial services through workshops because investors are more inclined towards organized marketing. not matter to actual investors - either positively or negatively. It turns out that potential investors certainly acknowledge that these instruments have risks and are keen to follow them consciously and, following the results. Additionally, a possible explanation for this result is the fact that the willingness to invest does not always coincide with actual investment. So, there are sometimes significant differences between intended and actual actions. In general, both variables reflect that these financial instruments are (potentially) acquired by persons who have a certain financial affinity and risk tolerance and not completely by greenhorns in financial investments. 


\section{Limitations and Direction for Future Study}

The results show the existence of a long-term relationship between short and long-term financial market indicators and economic and investment growth. The results also confirm that long-term financial instruments work better than short-term instruments in strengthening the country's economy in the short term, while in the long term, short and long-term financial indicators of traded stocks, credit banking, stock turnover, market capitalization and investment positively affect investment growth. We recommend that banks and financial markets in Libya consider enhancing bank credit by encouraging and facilitating investment, enhancing domestic investment, and improving long-term growth. The better the economic institutions are in a country, the less physical loss and higher economic growth rates. Improving the economic institutions and making more physical capital investment flow into productive activities can solve the problem of per capita income gap among countries. Besides, countries should not only focus on the improvement of economic institutions. The improving economic institutions should adapt the current technology, which will together promote the economic growth or will lead to positive effect, so the conclusions not only explain the process of economic growth in Libya since reform and open-up, but also provide some inspiration for the economic institutions reform in other developing countries.

\section{References}

Abdul-Rahman, A., Abdul Latiff, R., Muda, R. and Abdullah, M. A. (2014). Failure and potential of profit-loss sharing contracts: a perspective of new institutional economic (NIE) theory, Pacific Basin Finance Journal, Vol. 28, pp. 136-151.

Abdussalam, Z. (2014). The influence of cultural and religion on trust in the emerging financial market in Libya. International Journal of Behavioral Accounting \& Finance, 4(3), 206-220.

Abuselidze, G. (2018). Georgia's capital market: Functioning Problems and Development Directions in Association with EU. Journal of Applied Economic Sciences, Volume XIII, Winter, 7(61).

Abuselidze, G., \& Slobodianyk, A. (2019, September). Investment of The Financial Instruments and Their Influence on the Exchange Stock Market Development. In Economic Science for Rural Development Conference Proceedings (No. 52).

Alam, N. and Rizvi, S. A. R. (2017). Empirical Research in Islamic Banking: Past, Present, and Future in Islamic Banking: Growth, Stability and Inclusion, Palgrave Macmillan, pp. 1-13.

Aljbiri, A. (2013). The performance of Libyan stock market. Act Universities Agriculture et Silviculturae Mendelianae Brunensis, 60(7), 27-38.

Banerjee, S., Davis, J., Gondhi, N. (2018). When transparency improves, must prices reflect fundamentals better? Rev. Financ. Stud. 31, 2377-2414. 
Ben-David, Itzhak, Francesco Franzoni, and Rabih Moussawi (2017). Exchange Traded Funds. Annual Review of Financial Economics 9: 169-19.

Bloom, N., Brynjolfsson, E., Foster, L., Jarmin, R., Patnaik, M., Saporta-Eksten, I., \& Van Reenen, J. (2018). What drives differences in management practices? American Economic Review forthcoming.

Boyd, J. H., \& Smith, B. D. (1998). The evolution of debt and equity markets in economic development. Economic Theory, 12(3), 519-560.

Burch, D., \& Lawrence, G. (2013). Financialization in agri-food supply chains: Private equity and the transformation of the retail sector. Agriculture and Human Values, 30(2), 247-258. doi:10.1007/s10460-012-9413-7.

Calesso, A., Conti, M., \& Grasselli, M. (2020, August). Cyber Wolf: assessing vulnerabilities of ICT-intensive financial markets. In Proceedings of the 15th International Conference on Availability, Reliability and Security (pp. 1-7).

Castro, F., Kalatzis, A. E. G., \& Martins-Filho, C. (2015). Financing in an emerging economy: Does financial development or financial structure matter? Emerging Markets Review, 23, 96-123. https://doi.org/10.1016/j.ememar.2015.04.012.

Chen, Q., Huang, Z., Jiang, X., Zhang, G., Zhang, Y. (2018). The Role of asymmetric disclosure when price efficiency affects ral efficiency. Working Paper, Available at: SSRN: https://ssrn.com/abstract.3157447.

Chen, Q., Huang, Z., Zhang, Y. (2014). The effects of public information with asymmetrically informed short-horizon investors. J. Account. Res. 52, 635e669.

Chikulaev, R. V. (2020). Use of financial instruments to increase the capitalization of agroindustrial complexes. In BIO Web of Conferences (Vol. 17, p. 223). EDP Sciences.

$\mathrm{Chu}$, L. K. (2020). Financial structure and economic growth nexus revisited. Borsa Istanbul Review, 20(1), 24-36.

Clapp, J. (2019). The rise of financial investment and common ownership in global agrifood firms. Review of International Political Economy, 26(4), 604-629.

Clapp, J., \& Isakson, S. R. (2018). Speculative harvests: Financialization, food, and agriculture. Halifax, NS: Fernwood.

Demirguc-Kunt, A., Feyen, E., \& Levine, R. (2013). The evolving importance of banks and securities markets. World Bank Economic Review, 27(3), 476-490. https://doi.org/10.1145/3132847.3132886.

Faggio, G., O. Silva and W. C. Strange (2017). Heterogeneous agglomeration, Review of Economics and Statistics, 99, 80-94.

Fairbairn, M. (2014). Like gold with yield: Evolving intersections between farmland and finance. Journal of Peasant Studies, 41(5), 777-795. doi:10.1080/03066150.2013.873977.

Ferracuti, E., \& Stubben, S. R. (2019). The role of financial reporting in resolving uncertainty about corporate investment opportunities. Journal of Accounting and Economics, 68(2-3), 101248.

Ghosh, J. (2010). The unnatural coupling: Food and global finance. Journal of Agrarian Change, 10(1), 72-86. doi:10.1111/j.1471-0366.2009.00249. 
Gjika, D., Horvath, R. (2013, July). Stock market comovements in Central Europe: Evidence from the asymmetric DCC model. Economic Modelling, p.33, pp. 5564. https://doi.org/10.1016/j.econmod.2013.03.015.

Goldstein, I., Yang, L. (2019). Good disclosure, bad disclosure. J. Financ. Econ. 131, $118 \mathrm{e} 138$.

Halbert, Ludovic, \& Attuyer, Katia (2016). Introduction: The Financialization of urban Production: Conditions, mediations and transformations. Urban Studies, 53(7), 1347-1361.

Han, B., Tang, Y., Yang, L. (2016). Public information and uninformed trading: implications for market liquidity and price efficiency. J. Econ. Theory 163, $604 \mathrm{e} 643$.

Harrison, B., \& Moore, W. (2012). Forecasting Stock Market Volatility in Central and Eastern European Countries. Journal of Forecasting, 31(6), pp. 490-503. https://doi.org/10.1002/for.1214.

Hepsag, A. (2016). Asymmetric stochastic volatility in central and eastern European stock markets. Theoretical and Applied Economics, 607(2), pp. 135-144. Retrieved from http://store.ectap.ro/articole/1187.pdf.

Iqbal, N. and V. Daly (2014). Rent seeking opportunities and economic growth in transitional economies. Economic Modelling 37, 16-22.

Isola, W. A., Mesagan, E. P. (2016). Determinants of pharmaceutical industry's performance in Nigeria, Managing Global Transitions,14(3 (Fall)): 267-282.

Jalloh, M. (2009). The role of financial markets in economic growth, WAIFEM Regional Course on Operations and Regulation of Capital Market, 27-31 July 2009, Accra, Ghana.

Kerr, W. R. and S. D. Kominers (2015). Agglomerative forces and cluster shapes, Review of Economics and Statistics, 97, 877-99.

Khan, U., Aadil, F., Ghazanfar, M., Khan, S., Metawa, N., Muhammad, K., ... Nam, Y. (2018). A Robust Regression-Based Stock Exchange Forecasting and Determination of Correlation between Stock Markets. Sustainability,10(10),3702. doi.org/10.3390/su10103702.

Langlois, R. N. (2017). The institutional approach to economic history: Connecting the two strands. Journal of Comparative Economics 45(1), 201-212.

Lettau, Martin, and Ananth Madhavan (2018). Exchange-Traded Funds 101 for Economists. Journal of Economic Perspectives 32: 135-54.

Li, Z., Chu, Y., \& Gao, T. (2020). Economic Growth with endogenous economic institutions. Macroeconomic Dynamics, 24(4), 920-934.

Liu, G., \& Zhang, C. (2018). Does financial structure matter for economic growth in China. China Economic Review, https://doi.org/10.1016/j.chieco.2018.06.006.

Luintel, K. B., Khan, M., Leon-Gonzalez, R., \& Li, G. (2016). Financial development, structure and growth: New data, method and results. Journal of International Financial Markets, Institutions and Money, 43, 95-112. https://doi.org/10.1016/j.intfin.2016.04.002. 
Lusardi, A., Michaud, P. C., \& Mitchell, O. S. (2017). Optimal financial knowledge and wealth inequality. Journal of Political Economy, 125(2), 431-477.

Madhavan, A. (2016). Exchange-Traded Funds and the New Dynamics of Investing. Oxford University Press: New York, NY.

Madhavan, Ananth (2016). Exchange-Traded Funds and the New Dynamics of Investing. Oxford: Oxford University Press.

Marszk, A., \& Lechman, E. (2020). Application of Diffusion Models in the Analysis of Financial Markets: Evidence on Exchange Traded Funds in Europe. Risks, 8(1), 18.

McCann, P., \& Van Oort, F. (2019). Theories of agglomeration and regional economic growth: a historical review. In Handbook of regional growth and development theories. Edward Elgar Publishing.

Mesagan, E. P., Amadi, A. N. (2017). The efficiency market theory: A case of commercial banks stocks in Nigeria, Ovidius University Annals, Economic Sciences Series, 17(2): 583-587.

Mesagan, E. P., Nwachukwu, M. I. (2018). Determinants of environmental quality in Nigeria: Assessing the role of financial development, Econometric Research in Finance, 3(1): 55-78. DOI: 10.33119/ERFIN. 2018.3.1.3.

Nawaz, S. (2015). Growth effects of institutions: A disaggregated analysis. Economic Modelling 45,118-126.

Ndikumana, L. (2005). Financial development, financial structure, and domestic investment: International evidence. Journal of International Money and Finance, 24(4), 651-673.

Nikolaev, B. and R. Salahodjaev (2017). Historical prevalence of infectious diseases, cultural values, and the origins of economic institutions. Kyklos 70(1), 97-128.

Okicic, J. (2014). An Empirical Analysis of Stock Returns and Volatility: The Case of Stock Markets from Central and Eastern Europe. South East European Journal of Economics and Business, 9(1), 7-15. https://doi.org/10.2478/jeb-2014-0005.

Rodrik, D. (2017). Straight talk on trade: Ideas for a sane world economy. Princeton, NJ: Princeton University Press.

Rodrik, D., Subramanian, A., \& Trebbi, F. (2004). Institutions rule: The primacy of institutions over geography and integration in economic development. Journal of Economic Growth, 9(2): 131-165.

Shaydurova, A., Panova, S., Fedosova, R., \& Zlotnikova, G. (2018). Investment Attractiveness of "Green" Financial Instruments. Journal of Reviews on Global Economics, 7, 710-715.

Valoral Advisors (2010). 2011 global food \& agriculture investment outlook. Retrieved from: https://www.valoral.com.

Valoral Advisors (2015). 2015 global food and agriculture investment outlook. Issue 5. Retrieved from: https://www.valoral.com.

Valoral Advisors (2018a). Global food \& agriculture investment outlook. Issue 8. Retrieved from: https://www.valoral.com. 
Wietzke, F. B. (2015). Long-term consequences of colonial institutions and human capital investments: Sub-national evidence from Madagascar. World Development 66, 293-307.

Yavas, B. F., Dedi, L. (2016). An investigation of return and volatility linkages among equity markets: A study of selected European and emerging countries. Research in International Business and Finance, 37, pp. 583-596. https://doi.org/10.1016/j.ribaf.2016.01.025.

Yen, C. C., Huang, H. C. R., \& Lin, P. C. (2013). Financial structure on growth and volatility. Economic Modelling, 35, 391-400. https://doi.org/10.1016/j.econmod.2013.07.034.

Zakharkin, O., Zakharkina, L., Antoniuk, N. (2018). A comparative analysis of stock market volatility depending on investment time horizon. Economic Annals-XXI, 167(9-10), pp. 49-52. https://doi.org/10.21003/ea.V167-10. 
Abdulbaset Ali Alhaj, Abdullah Mohammed Awn, Al Taher Khalifa Abdusalam Alaswed FINANCIAL INSTRUMENTS AND THEIR IMPACT ON THE GROWTH OF INVESTMENT A STUDY ON THE LIBYAN MARKET

Creative Commons licensing terms

Authors will retain copyright to their published articles agreeing that a Creative Commons Attribution 4.0 International License (CC BY 4.0) terms will be applied to their work. Under the terms of this license, no permission is required from the author(s) or publisher for members of the community to copy, distribute, transmit or adapt the article content, providing a proper, prominent and unambiguous attribution to the authors in a manner that makes clear that the materials are being reused under permission of a Creative Commons License. Views, opinions and conclusions expressed in this research article are views, opinions and conclusions of the author(s).Open Access Publishing Group and European Journal of Economic and Financial Research shall not be responsible or answerable for any loss, damage or liability caused in relation to/arising out of conflict of interests, copyright violations and inappropriate or inaccurate use of any kind content related or integrated on the research work. All the published works are meeting the Open Access Publishing requirements and can be freely accessed, shared, modified, distributed and used in educational, commercial and non-commercial purposes under a Creative Commons Attribution 4.0 International License (CC BY 4.0) 